\title{
v Forum Edukatorów Archiwalnych, Łódź 17-18 IX 2018 r.
}

W dniach 17-18 IX 2018 r. w Łodzi odbyła się kolejna edycja Forum Edukatorów Archiwalnych. Piąte forum zostało zorganizowane przez Sekcję Edukacji Archiwalnej Stowarzyszenia Archiwistów Polskich, Wydział Filozoficzno-Historyczny Uniwersytetu Łódzkiego, Archiwum Państwowe w Łodzi oraz Instytut Pamięci Narodowej Oddział w Łodzi. W wydarzeniu wzięło udział prawie sześćdziesięciu uczestników z całego kraju, którzy w swojej codziennej pracy edukatorskiej wykorzystują materiały archiwalne. Tym razem konferencja stała się okazją do wymiany doświadczeń, związanych z organizacją konkursów archiwalnych oraz do zastanowienia się nad ich rolą w procesie dydaktycznym.

Obrady rozpoczęły się w budynku Wydziału Filozoficzno-Historycznego Uniwersytetu Łódzkiego od wystąpienia dr Ewy Puls z Uniwersytetu Kazimierza Wielkiego w Bydgoszczy. Referentka przedstawiła swój autorski i działający od 1999 r. program „Bydgoszcz - moja mała Ojczyzna”, będący modelowym przykładem cyklicznego konkursu historycznego, organizowanego na szeroką skalę i kładącego nacisk na trwałe efekty. Adresowana do uczniów szkół podstawowych inicjatywa ma na celu zaangażowanie młodych ludzi w życie lokalnej społeczności oraz zachęcenie ich do samodzielnego odkrywania historii regionu. O sukcesie i znaczeniu tego projektu świadczyć może chociażby fakt, że informacja o udziale w konkursie pojawia się na świadectwach szkolnych uczniów, a przygotowywane przez uczestników „teczki pracy” okazują się bardzo cennym źródłem informacji dla badaczy historii regionu.

W dalszej części wystąpili Hubert Mazur i dr Agnieszka Rosa, którzy przedstawili krótki rys historyczny konkursów, organizowanych przez archiwa państwowe. Ich tradycja sięga lat 50. XX wieku. Choć w początkowym okresie dominowały konkursy wewnętrzne, przeznaczone dla archiwistów, to dość szybko zaczęto angażować w nie również użytkowników archiwów. Autorzy omówili rodzaje najczęściej współcześnie organizowanych konkursów archiwalnych, tworząc ich roboczą typologię i zachęcając uczestników obrad do wnoszenia ewentualnych uwag. 
Kolejne dwa wystąpienia zostały poświęcone konkursom organizowanym przez archiwa zagraniczne. Dr Zuzanna Jaśkowiak-Józefiak z Uniwersytetu Adama Mickiewicza w Poznaniu zaprezentowała najciekawsze projekty archiwalne, przeprowadzone w krajach hiszpańskojęzycznych, a Elżbieta Czajka z Archiwum Państwowego w Łodzi w swoim wystąpieniu skupiła się na działalności archiwów z kręgu anglojęzycznego. Referaty te okazały się źródłem inspiracji dla uczestników forum, którzy z uwagą słuchali o zagranicznym podejściu do zagadnienia popularyzacji wiedzy o archiwaliach.

$\mathrm{Z}$ dużym zainteresowaniem uczestników spotkało się również wystąpienie dr hab. Marleny Jabłońskiej na temat tego, jak istotną rolę odgrywają konkursy w działalności edukacyjnej archiwów. Prelegentka słusznie zauważyła, że tego typu inicjatywy powoli stają się swego rodzaju koniecznością w obrębie działań popularyzatorskich, jeżeli naszym celem jest stworzenie wokół instytucji trwałej grupy zaangażowanych użytkowników. Jabłońska zwróciła też uwagę, że organizując konkursy często zapominamy o tym, co nasze instytucje naprawdę mogą zyskać. Skupiamy się na nagrodach dla uczestników i nie dostrzegamy, że dobrze przeprowadzony konkurs przynosi nagrodę również nam - w postaci zwiększenia zainteresowania naszą pracą i częstszych wizyt użytkowników w naszych placówkach.

Następnie w programie przewidziane było zwiedzanie gmachu Instytutu Pamięci Narodowej w Łodzi, w trakcie którego pracownicy IPN opowiadali o swoich codziennych zadaniach. Z kolei popołudniowe obrady przeniesiono do budynku Instytutu Europejskiego w Łodzi. Tam pracownicy IPN opowiedzieli uczestnikom forum o grach i konkursach edukacyjnych, tworzonych przez Biuro Edukacji Narodowej IPN. Po krótkiej prezentacji działalności instytutu uczestnicy zjazdu mieli okazję zapoznać się z puzzlami edukacyjnymi „IV rozbiór Polski", wydanymi przez IPN.

Kolejny dzień obrad w całości poświęcono analizie konkursów przeprowadzanych przez poszczególne archiwa. Pracownicy archiwów w Łodzi, Płocku, Kaliszu, Siedlcach i Nowym Sączu oraz Ośrodka KARTA omówili przygotowywane przez siebie inicjatywy, zwracając szczególną uwagę na aspekty techniczne i wiążące się z nimi problemy. Uczestnicy zjazdu mieli okazję bliżej przyjrzeć się organizowanemu od przeszło dwudziestu pięciu lat konkursowi „Ad fontes!” kaliskiego archiwum, czy też problemom pojawiającym się przy ocenie prac plastycznych na przykładzie konkursu „Namaluj mnie”, przeprowadzanego przez łódzkich archiwistów. Duże zainteresowanie wzbudziło też wystąpienie Agnieszki Filipek z Archiwum Narodowego w Krakowie Oddział 
w Nowym Sączu, która na podstawie własnych doświadczeń opowiedziała o plusach i minusach współpracy z różnego rodzaju instytucjami (również prywatnymi przedsiębiorstwami) przy organizacji konkursów. Referat okazał się przydatny w szczególności tym uczestnikom, którzy dotychczas z różnych względów organizowali konkursy samodzielnie. Ostatnim punktem programu konferencji było zwiedzanie budynku Archiwum Państwowego w Łodzi, połączone z warsztatami z odczytywania tekstów spisanych cyrylicą.

Piąte Forum Edukatorów Archiwalnych było okazją do bliższego przyjrzenia się jednemu z przejawów działalności popularyzatorskiej i edukacyjnej archiwów, o którym niekiedy się zapomina. O ile wystawy, konferencje i różnego rodzaju warsztaty są stałym elementem działalności archiwalnej, o tyle wszelkiego rodzaju konkursy są najczęściej jednorazowymi i stosunkowo rzadko przeprowadzanymi wydarzeniami. Wynika to nie tylko z konieczności poniesienia kosztów tego typu inicjatyw, ale także z panującego niesłusznego przekonania, że konkursy nie przynoszą żadnych realnych zysków poza nagrodami dla uczestników. Tymczasem, jak pokazują przedsięwzięcia podejmowane przez polskich archiwistów, konkursy nie muszą być okazjonalną, krótką akcją o charakterze: „prześlij odpowiedź i wygraj”. Mogą stać się rozbudowanym, długofalowym projektem, który będzie miał nie tylko dużą wartość edukacyjną, lecz także przyciągnie do archiwum nowych użytkowników. 